\title{
Tobacco control policy development and progress in Georgia
}

\author{
George Bakhturidze \\ FCTC Implementation and Monitoing Center, Tbilisi, Georgia
}

\begin{abstract}
Georgia is one of the countries with the highest smoking rates in the World Health Organization (WHO) European Region. The STEPS survey conducted in 2016 by the WHO demonstrated that $31 \%$ of adult Georgians (57\% of men and $12.2 \%$ of women) use some kind of tobacco product. Tobacco consumption in Georgia causes 11,400 deaths annually, including at least 2,100 among non-smokers. This tobacco epidemic costs the country $2.43 \%$ of its GDP every year.
\end{abstract}

KEY WORDS: tobacco control, legislation, tobacco smoking, smoking prevalence, Georgia.

ADDRESS FOR CORRESPONDENCE: George Bakhturidze, FCTC Implementation and Monitoing Center in Georgia,

4 Vani St., 0119, Tbilisi, Georgia, e-mail: iayd@yahoo.com

\section{INTRODUCTION}

Georgia's National Tobacco Control Legislation was updated in May 2017, with most regulations taking effect on 1 May 2018. In general, smoking is now prohibited in public places and public transport, with a few exemptions. Bans on tobacco advertising, promotion and sponsorship are scheduled to take effect in 2021, and a display ban and plain packaging requirement in 2023.

The Georgian Parliament created a special consultative body for health promotion and prevention under its healthcare committee in October 2017. Its aim is for smoking prevalence in Georgia to decrease by $50 \%$ by 2030 , and to become a smoke-free country by 2040 . To achieve these goals, Georgia needs to:

- enforce its new comprehensive smoke-free regulations rigorously,

- continuously increase tobacco taxes,

- strengthen current regulations, including on e-cigarettes and novel tobacco products,

- promote full implementation of the Framework Convention on Tobacco Control (FCTC) and the European Union (EU) Tobacco Products Directive (TPD) \#40,

- join the FCTC's Illicit Trade Protocol to prevent illegal turnover of tobacco products,

- invest in sustainable tobacco control with appropriate government funding.

\section{SMOKING PREVALENCE AND TOBACCO AVAILABILITY}

Tobacco use in the former Soviet republic of Georgia has increased dramatically since 1990, mostly due to the transition from a state to a market economy and the arrival of the transnational tobacco companies (TTCs). Prevalence of tobacco use among men increased from $53.3 \%$ in 2001 to $59.8 \%$ in 2008 , and among women from $6.3 \%$ to $14.9 \%$ in the same period $[1,2]$.

Currently, Georgia is one of the countries with the highest smoking rates in the World Health Organization (WHO) European Region. The STEPS survey conducted in 2016 by the World Health Organization showed that $31 \%$ of adult Georgians (57\% of men and $12.2 \%$ of women) use some kind of a tobacco product, which exceeded both the average rate worldwide (23\%) and in Europe (29\%). The survey also revealed that $25.3 \%$ of adult smokers in Georgia had attempted to quit smoking during the previous year [3].

The prevalence of smoking among adolescents was alarmingly high in 2008, when it stood at $16 \%$ among 16 -year-olds. In this cohort, $12 \%$ were regular smokers and $1.1 \%$ consumed 20 or more cigarettes per day. Buying cigarettes was not a problem for $60 \%$ of the adolescents who participated in the study. Among them, 30\% had begun using tobacco products by the age of 14 and 
$10 \%$ by the age of 10 . Additionally, $87 \%$ of adolescents said they had a friend who smoked $[4,5]$. According to the latest survey, conducted in 2014 , as many as $12.3 \%$ of teenagers aged 13 to 15 years used tobacco products, including $16.5 \%$ of boys and $7.8 \%$ of girls [6].

In addition, the non-smoking population in Georgia is exposed to second-hand smoke daily, including more than $40 \%$ of children [4-7]. Finally, $77 \%$ of Georgians can easily buy tobacco products at points of sale [6].

\section{HEALTH BURDEN AND IMPACT OF SMOKING}

Tobacco consumption is the number one risk factor for lung cancer and other cancers, strokes, heart attacks and other cardiovascular diseases such as chronic obstructive pulmonary disease (COPD). It is also associated with infertility, congenital abnormalities, chronic diseases, and other severe health problems [8]. The cost of treating such diseases represents the direct economic burden that tobacco poses, and is very high.

The global tobacco epidemic kills nearly 7 million people each year, and over 890,000 non-smokers die from exposure to second-hand smoke. Around $80 \%$ of these people are residents of low- and middle-income countries [9]. Tobacco consumption in Georgia causes 11,400 deaths annually, among them at least 2,100 nonsmokers [10].

Besides mortality, the indirect impact of tobacco use is also significant, including a decrease in productivity and performance caused by tobacco-related diseases. These losses are both economic and social in character. The tobacco epidemic costs Georgia 2.43\% of its GDP each year [10]. It also harms the environment, contributing to fires and soil depletion $[11,12]$.

\section{TOBACCO TAXATION POLICY}

After the collapse of the Soviet Union, Georgia's government welcomed the tobacco industry by allowing them to sell tobacco tax-free. Between 1991 and 1997 there was no tax on either locally produced or imported cigarettes. This situation changed in 1997 when imported cigarettes were levied a specific excise and customs tax of $0.25 \mathrm{GEL}$ (0.19 USD) and 0.19 GEL (0.15 USD) per pack of filtered and non-filtered cigarettes, respectively [13]. Between 1998 and 2004 the tax rates remained stable, but their values were eroded by inflation, which hovered around 5\% for most years, with a peak of $19 \%$ in 1999 [14].

In 2005 , the tax more than doubled for imported filtered cigarettes and more than tripled for domestic filtered cigarettes. Tobacco companies had six months to prepare for this increase, allowing them to pre-purchase tax stamps with the lower 2004 value for release in 2005, thus achieving tax savings [15]. This maneuver resulted in an unexpected increase in tobacco tax revenue in the second part of 2004 and disappointing revenue in 2005. Tobacco excise tax revenue in 2005 was 72 million GEL, about 4.4 million less than in 2004 [15].
The tobacco industry was able to manipulate the story about the decline in tax revenue - which the industry itself had caused - in order to persuade the government to reduce the excise tax in 2006 'to decrease smuggling. This scheme was a devastating blow to Georgia's tobacco tax policy, and it took the country several years to restore the 2005 rates.

In 2010, the excise tax on imported and local cigarettes became equal. Periodic increases followed, beginning in 2013 [16].

Georgia adopted a mixed tobacco tax system in 2015 by adding an ad valorem component to the excise duty. The base for calculating the ad valorem tax is the retail prices set each year by order of the Ministry of Finance [16]. Following the latest increase, in 2017, filtered cigarettes now incur an excise tax of 1.70 GEL (0.7 USD) per 20 cigarettes, and non-filtered cigarettes incur an excise tax of 0.60 GEL (0.25 USD), regardless of their origin. Each pack is also levied a $10 \%$ ad-valorem $\operatorname{tax}[16]$

Excise taxes are levied on pipe/loose tobacco at 35 GEL (14.5 USD) per $1 \mathrm{~kg}$. This translates to $0.50 \mathrm{GEL}$ (0.2 USD) per pack, using $0.7 \mathrm{~g}$ of tobacco per cigarette, a rate lower than non-filtered cigarettes. Only about $2.5 \%$ of smokers in Georgia use roll-your-own tobacco (ISSA 2016). All tobacco products are also subject to $18 \%$ VAT [16].

On August 1, 2017, Georgia began to tax e-cigarettes (0.2 GEL, or $0.08 \mathrm{USD}$, per $1 \mathrm{mg}$ of liquid) as well as cartridge and IQOS devices (1.7 GEL, or 0.7 USD, per piece) [16].

\section{TOBACCO CONTROL LEGISLATION}

Georgia's parliament adopted its first tobacco control law in 2003. In December 2005 it ratified the WHO Framework Convention on Tobacco Control (FCTC), which came into force in the country on May 15, 2006. Georgia modified its tobacco control law in 2008, but no enforcement mechanisms were added $[17,18]$.

In 2013, the Georgian government adopted two decrees laying out the main directions for tobacco control in the country. Decree № 196 on the Approval of a Tobacco Control National Strategy stipulated concrete, measurable objectives, an action plan, as well as tobacco tariff and tax measures on tobacco products [19]. Subsequently, a National Action Plan on Tobacco Control was adopted for the purposes of implementing the National Strategy [20].

The most recent legislative changes were made in May 2017, and most regulations took effect on 1 May 2018. In general, current regulations 1) prohibit smoking in public places and public transport with a few exemptions, 2) completely ban tobacco advertising, promotion and sponsorship, outdoor and indoor, as of 2021,3) ban tobacco product displays and mandate plain packaging, as of 2023 [21]. 


\section{PUBLIC ATTITUDES TOWARDS TOBACCO CONTROL MEASURES}

The majority of Georgians support the strengthening of tobacco control measures, including an increase in tobacco taxation. A 2008 survey of public attitudes towards the prohibition of tobacco promotion and advertising in public areas, at workplaces, in restaurants, and in public transportation, revealed that public support for such bans averaged $83 \%$. The strongest support was found in the age group of 56-70 years, where it reached $98.2 \%$. Between $88.6 \%$ and $98.9 \%$ of the surveyed non-smokers and ex-smokers supported the ban of all types of tobacco advertising, as did $73-82 \%$ of regular smokers [22].

Similarly, a survey published in 2012 demonstrated that the level of public support for restrictions on the tobacco trade (e.g. tobacco sales to minors, in individual pieces, $50 \mathrm{~m}$ distance from schools, etc. and penalties for non-compliance with tobacco control laws), is also high, on average at $85.2 \%$ [23].

The most recent legal changes strengthening tobacco control entered into force on 1 May 2018, and a survey conducted one month later showed that average public support for the provisions stood at $85 \%$, up from $79 \%$ in $2016[24,25]$.

\section{EU-GEORGIA ASSOCIATION AGREEMENT}

In June 2013, the European Union (EU) and the European Atomic Energy Community and their member states on one side, and Georgia on the other, concluded an Association Agreement, which includes a Deep and Comprehensive Free Trade Area [26].

The Association Agreement, much of which took effect in September 2014, set forth the framework for cooperation between the parties on measures strengthening tobacco control, and the harmonization of their laws in this field. In particular, Article 283 reads:

The Parties shall develop their cooperation and harmonise policies in counteracting and fighting fraud and smuggling of excisable products. This cooperation will include, inter alia, the gradual approximation of excise rates on tobacco products, as far as possible, taking into account the constraints of the regional context, and in line with the World Health Organisation Framework Convention on Tobacco Control. To that end, the Parties will look to strengthen their cooperation within the regional context.

Article 356 of the agreement reads as follows:

(c) prevention and control of non-communicable diseases, mainly through the exchange of information and best practices, promoting healthy lifestyles, physical activity, and addressing major health determinants, such as nutrition, addiction to alcohol, drugs and tobacco;

(f) effective implementation of international health agreements to which the Parties are party, in particular the International Health Regulations and the Framework Convention on Tobacco Control.
As to the latter, Georgia committed to submit within one year from the Association Agreement's effective date an implementation plan and schedule, including consideration of the country's needs regarding the fight against smuggling and protection of tax revenues.

Articles to be implemented within five years of the effective date of the agreement largely involve the terminology and classification of tobacco products. These articles, for which an implementation plan and schedule must be presented and agreed, determine the following:

- both types of excise duties shall be the same for all types of cigarettes and represent at least $60 \%$ of the weighted average retail sales price of cigarettes released for consumption. That excise duty shall not be less than 90 EUR per 1, 000 cigarettes. The excise tax may or may not include any customs fees and VAT;

- for cigars or cigarillos, excise duty shall be $5 \%$ of the retail sales price or 12 EUR per 1,000 pieces or per kilogram;

- from 1 January 2015, the excise duty on tobacco intended for the rolling of cigarettes shall represent at least $46 \%$ of the weighted average retail sales price, or at least 54 EUR per kilogram. From January 1, 2018, it shall be at least $48 \%$ of the retail sales price, or at least 60 EUR per kilogram, and from 1 January 2020, at least $50 \%$ of the retail sale price or at least 60 EUR per kilogram;

- for other types of smoking tobaccos the excise duty shall be $20 \%$ of the retail sales price, or 22 EUR per kilogram.

Moreover, within three years of the agreement's effective date, Georgia shall implement Council Directive 2007/74/EC [27] of December 2007, On the Exemption from Value Added Tax and Excise Duty of Goods Imported by Travellers from Third Countries [27].

The government of Georgia is implementing the agenda and Association Agreement based on the National Action Plan. In June 2014, Georgia and the EU agreed on the terms of the association agenda, thereby setting priorities for the implementation of their obligations prescribed by the Deep and Comprehensive Free Trade Area (DCFTA) components and the EU-Georgia Association Agreement for the years 2014-2016. The country developed the National Action Plan for 2015 that duly provided for the gradual increase of tobacco products excise rates, and their approximation to the rates prescribed by EU standards (per Article 285), and the implementation of the measures set forth in the National Action Plan for 2013-2018 on tobacco control in Georgia (per clause "f" of Article 356).

\section{ENDGAME POLICY AND RECOMMENDATIONS}

In 2017, the Georgian parliament created a special consultative body for health promotion and disease prevention under its healthcare committee. The body aims to halve tobacco consumption by 2030 and for Georgia 
to become a smoke-free country by 2040 . In order to achieve these goals, Georgia, similarly to Ukraine [28], needs to effectively enforce its smoke-free regulations, permanently increase taxes, strengthen regulations on e-cigarettes and novel tobacco products, and promote full implementation of the FCTC and the EU Tobacco Products Directive. The country also needs to join the FCTC's Illicit Trade Protocol to prevent illegal dealing in tobacco products. Proper investment in tobacco control, with appropriate funding from the government, will be crucial in achieving these goals.

\section{DISCLOSURE}

The author reports no conflict of interest.

\section{References}

1. Bakhturidze G, Ross H, What J, et al. Population survey on tobacco economy and policy in Georgia. FCTC Implementation and Monitoring Center in Georgia, Tbilisi 2008; 4-22.

2. Gilmore A, Pomerleau J, McKee M, et al. Prevalence of smoking in 8 countries of the former Soviet Union: results from the living conditions, lifestyles and health study. Am J Public Health 2004; 94: $2177-2187$

3. Sturua L. Non-communicable Diseases Risk-factors - STEPS survey. National Centre for Diseases Control of Georgia, Tbilisi, 2017. Available from: http://ncdc.ge/Handlers/GetFile.ashx?ID=993a23f3-d713-45ab-918a-eb53fe2b13f5 (accessed: 3 October 2018).

4. Baramidze L. The Alcohol and Other Drug Use in Georgian Students - ESPAD. Publishing-Advertising company - SAUNJE, Tbilisi 2009. Available from: https://untobaccocontrol.org/ impldb/wp-content/uploads/reports/georgia_annex2_espad alcohol_and_other_drug_use_in_georgian_students_2009.pdf (accessed: 3 October 2018)

5. Global Youth Tobacco Survey (GYTS), Georgia. 2008. Available from: https://nccd.cdc.gov/GTSS/rdPage.aspx?rdReport= OSH_GTSS.ExploreByLocation\&rdRequestForwarding=Form (accessed: 3 October 2018).

6. Global Youth Tobacco Survey (GYTS), Georgia. 2014. Available from: https://nccd.cdc.gov/GTSS/rdPage.aspx?rdReport= OSH_GTSS.ExploreByLocation\&rdRequestForwarding=Form (accessed: 3 October 2018).

7. Berg C, Topuridze M, Maglakelidze N. Reactions to smoke-free public policies and smoke-free home policies in the Republic of Georgia: results from a 2014 national survey. Int J Public Health 2016; 61: 409-416.

8. National Center for Chronic Disease Prevention and Health Promotion (US) Office on Smoking and Health. The Health Consequences of Smoking - 50 Years of Progress. A Report of the Surgeon General. Centers for Disease Control and Prevention (US), Atlanta 2014

9. WHO. Report: Global Tobacco Epidemics, 2017: monitoring tobacco use and prevention policies. 2017. Available from: http:// apps.who.int/iris/handle/10665/255874 (accessed: 3 October 2018).
10. Investment Case for Tobacco Control in Georgia. The case for investing in WHO FCTC implementation in Georgia. UNDP, WHO FCTC Secretariat, RTI International. 2018. Available from: http://www.ncdc.ge/Pages/User/News.aspx?ID=5aada9ce57aa-4ec5-9d81-915d43c388e9 (accessed: 3 October 2018).

11. Shafey O, Eriksen M, Ross H, Mackay J. Tobacco Atlas, third edition. American Cancer Society, Atlanta 2009.

12. Hall JR Jr. The Smoking-Material Fire Problem. USA National Fire Protection Association. Quincy, MA, 2013. Available from: https://www.nfpa.org/-/media/Files/News-and-Research/ Fire-statistics-and-reports/US-Fire-Problem/Fire-causes/ ossmoking.ashx?la=en (accessed: 3 October 2018).

13. Georgian Tax Code. Tbilisi, 1999. Available from: https:// matsne.gov.ge $/ \mathrm{ka} / \mathrm{document} / \mathrm{view} / 31690$ ?publication $=86$ (accessed: 3 October 2018).

14. Inflation on tobacco products. Letter from National Statistics Office of Georgia. Tbilisi, 2018.

15. Shalutashvili A, Ross H, Watt J, et al. Tobacco Economic Study in Georgia since the fall of the Soviet Union. FCTC Implementation and Monitoring Center in Georgia, Tbilisi 2007.

16. Georgian Tax Code. Tbilisi, 2018. Available from: https:// matsne.gov.ge $/ \mathrm{ka} /$ document $/$ view $/ 1043717$ ? publication $=142$ (accessed: 3 October 2018).

17. Georgian Law on Tobacco Control. Tbilisi, 2008. Available from: https://matsne.gov.ge/document/view/16126? publication $=4$ (accessed: 3 October 2018).

18. WHO Framework Convention on Tobacco Control. 2003. Available from: www.fctc.org.ge; https://treaties.un.org/pages/ViewDetails.aspx?src=TREATY \&mtdsg_no=IX-4\&chapter=9\&lang=en (accessed: 3 October 2018).

19. Georgian Tobacco Control National Strategy. Tbilisi, 2013. Available from: https://matsne.gov.ge/ka/document/view/1978972? publication $=0$ (accessed: 3 October 2018).

20. Georgian National Action Plan on Tobacco Control 20132018. Tbilisi, 2013. Available from: https://matsne.gov.ge/ka/ document/view/2096830?publication $=0$ (accessed: 3 October 2018).

21. Georgian Law on Tobacco Control. Tbilisi, 2017. Available from: https://matsne.gov.ge/document/view/1160150?publication $=3$ (accessed: 3 October 2018).

22. Bakhturidze GD, Mittelmark MB, Aaro LE, Peikrishvili NT. Attitudes towards smoking restrictions and tobacco advertisement bans in Georgia. BMJ Open 2013; 3: e003461.

23. Bakhturidze GD, Peikrishvili NT, Mittelmark MB, Aaro LE. The public's attitudes towards tobacco sales prohibition: evidence from a nationally representative survey in the former Soviet state of Georgia. Tobacco Control and Public Health in Eastern Europe 2012; 2: 99-108.

24. Study of attitudes toward tobacco use in public spaces. Institute on Social Studies and Analyses, Tbilisi 2016. Available from: http://issa-georgia.com/en/non-entrepreneurial-non-commercial-legal-entity/study-of-attitudes-toward-tobacco-use-inpublic-spaces-2016/10 (accessed: 3 October 2018).

25. Public attitudes in Georgia. National Democratic Institute by CRRC Georgia. Tbilisi, 2018. Available from: https://www.ndi. 
org/sites/default/files/NDI_June_2018_Presentation_Public ENG_vf.pdf (accessed: 3 October 2018).

26. Agreement between Georgia and EU on the Association Agreement. Gov. of Georgia, European Union. Brussels, 2014. Available from: https://matsne.gov.ge/ka/document/view/2496959?publication $=0$ (accessed: 3 October 2018)

27. Council Directive 2007/74/EC of 20 December 2007 on the exemption from value added tax and excise duty of goods imported by persons travelling from third countries. Available from: https://eur-lex.europa.eu/legal-content/EN/ALL/?uri= CELEX: 32007L0074 (accessed: 3 October 2018).

28. Olefir L. Tobacco control policies in Ukraine: history, public health impact, and current priorities. J Health Inequal 2018; 4: 13-17.

Dr. George Bakhturidze is a medical doctor and lawyer. He received a his Master's and PhD degrees in Health Policy and Promotion from the University of Bergen. Dr. Bakhturidze has been at the forefront of tobacco control and health promotion in Georgia, Europe, and globally since 1998. He is the Chairman of the Tobacco Control Alliance in Georgia and Associate Professor at the University of Georgia. 